\title{
7. 'Drugs, guns and gangs': Case studies on Pacific states and how they deploy NZ media regulators
}

\section{ABSTRACT}

Media freedom and the capacity for investigative journalism have been steadily eroded in the South Pacific in the past five years in the wake of an entrenched coup and censorship in Fiji. The muzzling of the Fiji press, for decades one of the Pacific's media trendsetters, has led to the emergence of a culture of self-censorship and a trend in some Pacific countries to harness New Zealand's regulatory and self-regulatory media mechanisms to stifle unflattering reportage. The regulatory Broadcasting Standards Authority (BSA) and the self-regulatory NZ Press Council have made a total of four adjudications on complaints by both the Fiji military-backed regime and the Samoan government and in one case a NZ cabinet minister. The complaints have been twice against Fairfax New Zealand media — targeting a prominent regional print journalist with the first complaint in March 2008 —and twice against television journalists, one of them against the highly rated current affairs programme Campbell Live. One complaint, over the reporting of Fiji, was made by NZ's Rugby World Cup Minister. All but one of the complaints have been upheld by the regulatory/self-regulatory bodies. The one unsuccessful complaint is currently the subject of a High Court appeal by the Samoan Attorney-General's Office and is over a television report that won the journalists concerned an investigative journalism award. This article examines case studies around this growing trend and explores the strategic impact on regional media and investigative journalism.

Keywords: accountability, censorship, Fiji, Fourth Estate, investigative journalism, media law, media regulation, media self-regulation, military regimes, Samoa

DAVID ROBIE

Pacific Media Centre 
7 HREATS to investigative journalism in the South Pacific and journalists with a track record of investigations in the region are mounting. In

L Papua New Guinea, for example, while no single dominant group of people may threaten journalists, 'there is always an element of risk because people whose misdeeds are exposed in the media have supporters, relatives or beneficiaries who may retaliate' (Matbob, 2011, p. 38). PNG Post-Courier reporter Haiveta Kivia, who won the region's inaugural 2011 UNDP Pacific Investigative Journalism Award for reporting corruption involving one of the country's leading secondary schools, a minister and land titles, has described a pattern of threats and victimisation of the families of investigative reporters (Yamo, 2012). Nevertheless, investigative journalism has 'become a crucial part of the media's Fourth Estate role' in the country and is relevant today in the face of rampant corruption and forestry and mining resource exploitation as in recent years (ibid). In Fiji, investigative journalism, after a proud track record in past years, notably the exposure of the National Bank of Fiji fiasco-'the biggest financial scandal in the history of Fiji' - when the stateowned NBF was 'running bad and doubtful debts to the tune of F\$90 million in the 1990s' which escalated to $\$ 220$ million (Grynberg et al., 2002), has collapsed since the fourth coup in November 2006.

While there are inconsistent pockets of investigative work offered by some Pacific journalists, such as at the Samoa Observer, the PNG Post-Courier, and the regional news magazine Islands Business, much of the limited transparency and accountability provided by media is actually offshore and done by news and current affairs groups based in Australia and New Zealand (UNESCO, 2011). But a surprising trend has emerged in recent years whereby two Pacific governments in particular, Fiji and Samoa, have resorted to using media regulatory and self-regulatory agencies in New Zealand to target individual journalists perceived to be a political embarrassment. Two high profile Pacific affairs journalists have been targeted in this way, Michael Field of Fairfax Media, and Barbara Dreaver of Television New Zealand. Both are highly experienced and skilful journalists who have conducted investigative work in the course of their reporting. In addition, Dreaver was born in Kiribati in Micronesia, worked in the Cook Islands and has a strong 'Pasifika' community identity. Both are banned by the Bainimarama regime while Field has also been barred from Kiribati (since lifted), Nauru and Tonga. A third journalist targeted is John Campbell, a widely respected journalist who anchors TV3's Campbell Live current affairs show.

106 PACIFIC JOURNALISM REVIEW 18 (1) 2012 
The New Zealand media regulatory model is based on a three-tiered structure: 1). The New Zealand Press Council (self-regulatory and headed by a retired judge with no powers other than to require voluntary publication of its rulings and it adjudicates about 45 print and online complaints a year); 2). the Broadcasting Standards Authority (BSA) (statutory regulator headed by a lawyer with the power to order fines and costs, and provides determinations for about 150 to 250 complaints a year); and 3). the Advertising Standards Authority (ASA) (self-regulatory with 1557 complaints about 493 advertisements in 2006-more than double the number of the previous year (Robie, 2009, p. 92). Only Fiji and Papua New Guinea have media councils with a well-established complaints process, ${ }^{1}$ although a fledgling Tongan Press Council is evolving. Of the four complaints filed by Pacific governments since 2008, three were through the BSA and the fourth was filed with the Press Council. All but one of the complaints have been upheld (see Table 1). The one unsuccessful complaint was at the time of going to press the subject of a High Court appeal by the Samoan Attorney-General's Office and was over a story that won the journalists concerned an investigative journalism award. This article provides an overview of these cases and explores the strategic implications for investigative journalism.

\begin{tabular}{|c|c|c|c|}
\hline Complaint & Date & Standards & Adjudication \\
\hline $\begin{array}{l}\text { NZ Press Council 2186: } \\
\text { McCully against Sunday Star-Times }\end{array}$ & May 2011 & $\begin{array}{l}\text { Accuracy, } \\
\text { fairness } \\
\text { and balance }\end{array}$ & Upheld \\
\hline $\begin{array}{l}\text { NZ Broadcasting Standards Authority } \\
\text { 2010-188: } \\
\text { Attorney-General of Samoa and TVWorks Ltd }\end{array}$ & $\begin{array}{l}5 \text { May } \\
2011\end{array}$ & $\begin{array}{l}\text { Accuracy, } \\
\text { fairness }\end{array}$ & Not upheld \\
\hline $\begin{array}{l}\text { NZ Broadcasting Authority 2009-066: } \\
\text { Attorney-General of Samoa and Television } \\
\text { NZ Ltd }\end{array}$ & $\begin{array}{l}2 \text { March } \\
2010\end{array}$ & $\begin{array}{l}\text { Balance, } \\
\text { accuracy, } \\
\text { fairness, law } \\
\text { and order }\end{array}$ & $\begin{array}{l}\text { Upheld, } \\
\$ 5000 \text { costs } \\
\text { to Samoan } \\
\text { govt, } \$ 2000 \\
\text { to crown }\end{array}$ \\
\hline $\begin{array}{l}\text { NZ Broacasting Standards Authority } \\
\text { 2008-040: } \\
\text { Pryde and Radio New Zealand Ltd }\end{array}$ & $\begin{array}{l}27 \text { August } \\
2008\end{array}$ & $\begin{array}{l}\text { Balance, } \\
\text { accuracy }\end{array}$ & $\begin{array}{l}\text { Upheld, } \\
\text { no order }\end{array}$ \\
\hline
\end{tabular}

Source: Robie, 2011. Compiled from NZ media regulatory or self-regulatory agency complaint adjudications, 2008-2011. 


\section{Case study 1: Pryde [Fiji] and Radio New Zealand Ltd-2008-040}

Broadcasting Standards Authority, 7 March 2008

Michael Field is a New Zealand journalist who has specialised in reporting Pacific affairs and, after working for Agence France-Presse for several years in that capacity, is now with Fairfax Media. Field (1984) is the author of Mau: Samoa's Struggle Against New Zealand Oppression, a definitive work on New Zealand's colonial record in the Pacific. As a reporter, he pulls no punches and has 'developed an extraordinary penchant for getting up the noses of paranoid and vindictive island authorities, making him persona non grata in Fiji, Kiribati, Nauru and Tonga' (Robie, 2010). His ban from Kiribati was lifted late in 2011 when President Anote Tong gave 'a great welcome to me in Tarawa in October and un-gazetted me' (M. Field, personal communication with the author, 12 January 2012).

On 7 March 2008, Radio NZ National Nine to Noon programme host Kathryn Ryan interviewed Field in one of his regular 'Pacific updates' on the station. He described the situation in Fiji as 'progressively getting worse' and that the regime's dictator, Commodore Voreqe Bainimarama, was showing 'all the signs of true military dictatorship'. Field observed that he had looked at a couple of websites before coming onto the programme and noted that Bainimarama had sacked his two military spokesmen, saying all future comments must come from him. Field also criticised the handling of the media and journalists by the regime:

And I'm just astonished this morning-the head of Fiji Broadcasting [Corporation], who is the brother of the military appointed AttorneyGeneral [Aiyaz Sayed-Khaiyum], and the head of broadcasting's a chap called Riyaz Sayed-Khaiyum, has come out and said well the military were doing right because his staff were reporting rumours. I think it says something when the military-appointed management of a media outlet can now justify the interrogation of their own journalists. It's a dangerous world in Fiji to be a journalist there. (Pryde \& Radio New Zealand Ltd, BSA, 27 August 2008, p. 1)

Field commented that the publisher of the Fiji Sun, Russell Hunter, had recently been deported for publishing revelations around Finance Minister Mahendra Chaudhry's tax returns, and the journalist's family had been given eight days to leave the country. Field added that there was no true media 
freedom in Fiji, and that journalists and any judges who showed independence were forced to 'worry about their future' (p. 2). He cited Australian High Court judge Justice Jocelynne Scutt as an example. She was reportedly

... robbed in the street after she actually attacked, well said she didn't agree with [then Fiji Human Rights Commissioner Dr] Shaista Shameem's assessment that the Fiji coup had been a legitimate coup. So the day after she did this she was robbed in the street and her house was burnt down. (Ibid.)

Fiji's Solicitor-General, Christopher Pryde, a New Zealander, declared he was 'outraged' by the programme and made a three-page formal complaint about it to broadcaster Radio New Zealand Ltd. on 19 March 2008 (rejected by the broadcaster almost a month later). He claimed that Field's 'update' was 'no more than an uneducated, ill-informed, deeply biased, unbalanced, and false account' of developments in Fiji (Fiji regime accuses Radio NZ, Fairfax journalist of bias, Stuff, 27 March 2008):

As a New Zealander residing in Fiji who does know the facts, unlike Mr Field, I am deeply concerned at the continual slanted and untruthful reporting of events in Fiji by sections of the New Zealand media, particularly Radio New Zealand. (Ibid.)

Pryde claimed that Field's distaste for the regime was obvious and Radio NZ's presenter Ryan had accepted the opinions uncritically apart from 'some silly giggling in the background' (Fiji regime, Stuff, March 27). He noted Field was not resident of Fiji and claimed his information 'appeared to come from websites and blogs' (Pryde \& Radio NZ, p. 2). Pryde also referred to 'emotive terms' used by Field, such as 'dragooning' (for a court summons), 'kangaroo court' and 'Star Chamber'(Court of Appeal), and 'preached' (for judges expressing concern), and claimed that the journalists comments verged on contempt of court.

Pryde also claimed that Field had defamed Riyaz Sayed-Khaiyum by stating he was a 'military appointee' when in fact he had been appointed after an 'exhaustive process of recruitment conducted by the Board of Fiji Broadcasting'. There was no military involvement. Pryde also said the family of editor Russell Hunter had been given 21 days to leave the country, not eight as stated 
by Field. Another 'blatant example' of inaccuracy was a reference by Field to the mugging of the judge and an attempt to link this to her 'opposition' to a Fiji Human Rights Commission report supporting the 2006 military coup (Pryde \& Radio NZ, p. 2). (Justice Scutt, in fact, took no position and there was no evidence that her house had been burned down).

The BSA determination accepted that the journalist was speaking in an 'off-the-cuff' manner but still needed to be 'clear and accurate'. The Authority ruled that Field was inaccurate in his statements that the head of Fiji Broadcasting was 'military appointed', editor Russell Hunter's family had been given eight days to leave, and that the High Court judge had been attacked because of her claimed opposition to the human rights report. Ultimately, the BSA upheld four complaints of inaccuracy and declined to uphold the balance complaint as Field was giving 'expert opinion' as a commentator. However, it added the rider that the decision would 'serve as a reminder to commentators that they must ensure the accuracy of factual statements' (Pryde \& Radio NZ, p. 9).

When the state broadcaster reported gleefully on the BSA ruling in an item headed 'STANDARDS BODY SLAMS FIELD', others in the Fiji media, such as The Fiji Times and the Fiji Sun, followed suit (Standards body, FBC, 15 September 2008). Field himself commented on his own website:

What is more astonishing, is that both newspapers lost their publishers in military deportations, but, in the new, tame age, now accept their versions of what happened from the Fiji government. Not only are they completely gutless, they have lost the ability to read freely available documents themselves!

They would rather take the word from some unnamed Fiji government hack spin doctor. That is the same Fiji government that had me seized and deported. In addition, had their own publishers seized and deported.

Are their reporters such mice; or are they so intimidated? (Michael Field fields it as it is, Discombulated Bubu, 16 September 2008)

\section{Case study 2: Samoa v. Television NZ over 'Gangs, drugs and guns'}

Broadcasting Standards Authority, 6 April 2009

Television New Zealand's Pacific affairs correspondent Barbara Dreaver is the only TV journalist in the country specialising in the region. She is passionate about her job "because of her cultural heritage" (born and raised in 
Kiribati and having spent eight years working as a journalist in the Cook Islands) (TVNZ staff profile, 2011). She has also brought a committed investigative edge to reporting the region and is widely respected.

An item broadcast on TVNZ's One News on 6 April 2009 reported that an investigation by Dreaver had exposed a 'lucrative trade' in drugs from New Zealand that was 'in turn helping pay for the smuggling of some heavy weaponry from the US and China'(Dreaver, 2009). Dreaver explained in the report that she had been on assignment in Samoa for a week and had discovered that while 'gun smuggling has been a problem for many years', it was now a combination between drugs coming from New Zealand and China, 'combined with young thugs who have no history of Samoan culture' (BSA adjudication, 2009-066, 2010, p. 2). She talked to a group of 'gangsta' style Samoan youths, known as the 'Makoi boys', who allegedly ran a marijuana and 'P' business. The news item portrayed them wielding these weapons, including machetes, or can knives, and smoking. Dreaver also reported that smuggling guns from the US was 'becoming big business'. From a 'secret location', she provided viewers with a quick view of available weapons (including those in a car boot)—and the going price.

In the One News studio, a news presenter asked reporter Dreaver how the Samoan police had reacted to the situation. Dreaver replied:

Well, the Police Commissioner [Papali'i Lorenese Neru] wouldn't appear on camera but he did tell One News that most of the guns in Samoa are used for sport. We know that's not the case. And he also said there's not really a hard drugs problem in Samoa. We also know that's not the case. And perhaps one of the reasons the Police Commissioner did not want to appear on camera is that he has been accused of gun smuggling himself. A gun commission found he did have a case to answer for but he was not investigated because the Samoan cabinet voted he shouldn't be. (BSA 2009-066, 2010, p. 2; Samoa's police commissioner reprimanded, Sioa, n.d.)

Dreaver was referring to a Samoan Commission of Inquiry in November 2008 that examined allegations that police officers smuggled guns into the country from neighbouring American Samoa on the police patrol boat MV Nafanua (Samoa police commissioner provides testimony, gunpolicy.org, 22 November 2008; Samoa police commissioner, 15 November 2008); Sioa, 
(n.d.). The Samoan Office of the Attorney-General alleged Commissioner Neru claimed while giving evidence before the Commission he had received a 'faamomoli' (package) from former American Samoa police captain Papali'i Marion Fitsemanu. Neru claimed he was 'shocked' when he discovered firearms inside but he never disclosed this find to anybody else. Yet while the Commission later found both Neru and Nafanua skipper Logoitino Filipo in breach of duty and recommended criminal investigation, the police dropped any prosecution. However, the cabinet demoted Filipo and censured Neru (Sioa, n.d., Two senior Samoa police officers escape criminal charges, Radio NZ International, 30 January 2009).

Three days after the One News report, at $10.55 \mathrm{pm}$ on 9 April 2009, the half-hour TVNZ weekly magazine programme Tagata Pasifika broadcast an expanded version. This item also included comments from Michael Hickey, a Kiwi expatriate tattooist, who talked about how the deportees struggled to adapt to the matai (chiefly) village system in Samoa, and another former gang member who had been deported from the US.

The Samoan Attorney-General later alleged in a complaint to the BSA the reporter had sought to show illegal guns and brought alcohol in exchange. The AG said:

They [Makoi boys] were never told the filming and interviews were for a TVNZ One News story about gangs and drugs in Samoa (in fact, they were led to believe it was for a documentary on deportees adapting to life in Samoa and other Pacific islands and /or gangsters around the world).

They were 'acting up' for the camera based on instructions from [the reporter] as to what she wanted to see. (BSA, 2009-066, 2010, p. 3).

The Office of the AG alleged that TVNZ had obtained film footage and interviews using 'inaccurate and unfair' methods and 'distorting' the original events. It challenged the veracity of several news scripted statements, including 'criminal gangs are building up a terrifying arsenal', 'a lucrative trade in drugs from New Zealand' helping fund the 'smuggling of some heavy weaponry from the United States and China', 'guns of all sizes are being smuggled in from the US and it's becoming big business' and the 'police ... generally turn a blind eye' (BSA, 2009-066, 2010, p. 4). The complaint was filed citing broadcasting standards 2 (law and order), standards 4 (balance), 5 (accuracy), and 6 (fairness). 
Television New Zealand dismissed the complaint as being based solely on the state-owned company's allegedly "“duplicitous" behaviour' in the filming and interviews cited, stating that these were just part of a 'wider investigation by the reporter into drugs and guns in Samoa' (BSA, 2009-066, 2010, p. 5). Examples of the wider context were an interview with a masked man, footage of guns in a car boot and their price list, and comments by security specialist Herman Sakaria who said that 'if South Auckland had access to the guns that you get here in Samoa, South Auckland would be a war zone' (p. 2). Television New Zealand also provided a file of several official reports, Samoan news media reports about the 'growing problem with guns and drugs in Samoa' and also the regular use of machetes as weapons along with its defence of the news items (p. 6). Sworn affidavits from Dreaver and her two news crew colleagues defending the reporter's integrity were attached in support. The network also pointed out that Samoan police 'initially made some arrests and ... increased maritime surveillance and calling on village councils to report suspicious activity'.

After two rounds of seeking further information from both the AttorneyGeneral and Television New Zealand, the BSA delivered its ruling. The BSA found that both the One News and Tagata Pasifika news items were a 'controversial issue' in which the balance standard applied:

Given that New Zealand is home to a significant Pacific Island community, and that New Zealand has strong historical ties with Samoa, the BSA disagrees with TVNZ that the issue was not of public importance in New Zealand. The fact that One News is broadcast every night on two television channels in Samoa demonstrates a close link between the countries. The Authority also notes that the items specifically referred to methamphetamine being smuggled to Samoa from New Zealand ... The reporter also stated that there were 'several drug lords' in Samoa. (BSA, 2009-066, 2010, p. 16)

The BSA ruled that the 'cumulative effect of such a dramatic introduction' with other information created an impression for viewers of a serious situation in Samoa with government officials being complicit in the guns and drugs trade. It concluded that Television New Zealand 'only presented one perspective'. While the Tagata Pasifika item was 'more moderate' than the One News item, both were found to have breached the balance standard (p. 19) The Authority also partially upheld the accuracy and fairness complaints while not upholding 
the law and order standard 'encouraging or condoning criminal activity' complaint. Television New Zealand was ordered to pay $\$ 5000$ costs to the Samoan government, $\$ 2000$ to the Crown and broadcast a statement about the ruling (p. 25).

The Samoan Prime Minister and sections of the local news media immediately praised the BSA ruling. Tuila'epa Sa'ilele Malielegaoi described the ruling as a 'victory for responsible and substantive ruling'. He added: 'There have been far too many incidences of unbalanced reporting with reporters and editors alike bent on producing and publishing half-cooked, sensationalised stories with the sole aim of stirring up controversy' (Francis, 2010). Pacific Eyewitness publisher Vienna Richards, a New Zealand-based Samoan publicist, was also quick to go on the attack:

Regardless of how TVNZ-a publicly funded broadcaster-spins this story, the [BSA], who [sic] are not reknown [sic] for ruling against the broadcaster, issues some clear findings. TVNZ and its Pacific correspondent made some big mistakes [blog author's emphasis] on this story. Basic errors of journalism practice. That is clear from this decision and its findings. The story about guns and drug smuggling in Samoa was found to be unbalanced, inaccurate on one of two counts and unfair on one of two counts. (Richards, 2010, p. 1)

A four-page critique of the BSA ruling and Dreaver's alleged ethical transgressions followed on the website, which praised BSA for not 'accepting the word of the broadcaster' (p. 2). Two years earlier, Dreaver had exposed a so-called 'political appointment' of Richards to a publicly funded Pacific Radio Network news director position - (her brother is William Sio, Labour Party MP for Mangere) (Robie, 2008). But Dreaver also had her defenders. Café Pacific, for example, chastised the Samoan government for breaking the embargo in its race to gloat over the BSA ruling:

So the Samoan government has jumped the gun on the Television New Zealand 'gangsta paradise' affair. In its eagerness to win a political point or two over the state-owned broadcaster (which incidentally has just supplied a 'Pacific TV' gift of broadcast equipment to Samoa) in its long-standing controversial complaint about TVNZ accuracy, fairness and ethics, the government has itself breached the broadcast industry's watchdog embargo. This is a violation of an important part 
of the adjudication process, which enables both parties to prepare their response to the orders and to consider an appeal. In fact, Café Pacific wonders what part of the 'NOT FOR PUBLICATION' label stamped on each page of the draft ruling, the Samoan government officials did not understand. If it was a court, this would be contempt. (Robie, 2010a)

\section{Case study 3: Samoa Attorney-General and TV3's Campbell Live}

Broadcasting Standards Authority, 27 September 2010; 1 November 2010 Campbell Live is TV3's flagship current affairs programme in New Zealand. Presenter John Campbell has been a journalist for more than 20 years, including as a fulltime political reporter based in the gallery in Wellington covering six elections. In 2005, the same year as the Campbell Live debut, he won the premier Qantas Award for 'best news investigation'. As a political interviewer he has spoken to leaders throughout the Asia-Pacific region and the politicians heading the Fiji regime, Samoa, Solomon Islands, Tahiti and Tonga. In the five-year-old Campbell Live's first year it won both Qantas Television Awards 'Investigation of the Year' and 'Best News Report Team Award' (Week nights on Campbell Live, TV3, 30 August 2011).

On 27 September 2010, Campbell Live broadcast an item reflecting on the first year anniversary of a tsunami that struck Samoa a year earlier to the day. In his introduction, presenter John Campbell noted that the Samoan government had received a total of 192 million tala (NZ\$102 million) in donations from the international community, and questioned: 'Where has all the aid money gone?' (Samoa tsunami, Campbell Live, 27 September 2010). The journalist travelled to Samoa and visited the communities devastated by the tragedy. Footage of him walking in one of the areas was shown while he said:

I'm high in the hills above Saleapaga. This is the loo for this little community. There is no rain water, no way to flush it, no way to wash your hands after using it. Come with me. This is the house that this one family is living in. It is completely ramshackle. It will not survive a good strong wind in the cyclone season which is on its way (BSA, 2011, p. 2).

Mata'afa Keni Lesa, editor of the Samoa Observer, was interviewed, saying: 'The standard of living out there is just appalling. It's pathetic for, you know, one year later.' Campbell then spoke to affected local Samoans who told him they had no water supply, and had received 'no money' from the govern- 
ment. Mata'afa added a comment that some families did have water-but they needed to boil it for drinking.

Campbell Live also interviewed Deputy Prime Minister Misa Telefoni who said on camera: 'I guess the important thing is to balance people's needs and people's wants. We've been working very, very hard to ensure their needs are met.' Reporter Campbell added in his voice over, Telefoni was 'more measured than his boss' who had been overseas, but when he spoke to Tagata Pasifika in a 'response that was almost bizarre', he declared: 'You don't seem to put your mind off [the tsunami]. It's no longer a newsworthy issue.' The Campbell Live report continued:

On the coast, the no longer newsworthy people are waiting; it's just that they are not really sure what for. Some of the homes they have settled into, and are being born into, are shockingly substandard. They were meant to be temporary, which everyone understood, but they seem somehow to have become permanent. No electricity, no water-is this really what everyone who donated to the reconstruction had in mind? Where did that money go? (BSA, 2011, p. 2)

Deputy Prime Minister Telefoni said about 5 million tala (NZ\$3 million, or about 75 percent of the aid funds allocated for the purpose) had been used. Campbell asked was that 'woefully inadequate in hindsight?' for reconnecting water to the coastline.

On 1 November 2010, Campbell Live broadcast a follow-up item that again asked: 'Where has the tsunami relief money gone?' In his introduction, Campbell noted the Samoan government was 'outraged' by the first story and continued:

Yes, there are new roads and electricity is back in the region. The government says they've spent 68.7 million tala (NZ\$38 million) so far. But many tsunami victims feel deserted by their government and wonder why so little of the money has made its way to them. And the documents we've obtained suggest many millions more dollars have been received than have been spent around the coastline. (BSA, 2011, p. 3)

After interviewing Samoan villagers who stated they had received no financial assistance from their government, Campbell cited the Samoan Prime Minister for being 'critical of our last story': 'He called me stupid, stupid and stupid, blind, unbalanced and a palagi.' (BSA, 2011, p. 3). Campbell went 
on to say that the Campbell Live report was partially based on statistics (a graphic of a document was screened) provided by the Samoan government itself.

Prime Minister Tuila'epa and Campbell had an 'on-camera confrontation outside an Apia restaurant' during a door-stepping episode in the investigation of the alleged scandal around tsunami relief funds (Robie, 2010b). The Attorney-General later made formal complaints about both TV 3 current affairs items, alleging they breached accuracy and fairness broadcasting standards (Hill, 2011). Campbell accused the Prime Minister of being a 'coward' for not fronting up to an arranged interview and Samoa Observer editor-in-chief branded the New Zealand journalist Tuila'epa's 'Kiwi nemesis' (Campbell calls PM a 'coward', Samoa Observer, 29 October 2010; Robie, 2010b). The BSA's ruling did not uphold the complaints, saying the Samoan government was given fair and reasonable opportunity to respond to Campbell's programme.

In the ruling, the BSA ruled that it was not its role to-nor was it able to-'determine what action by the Samoan government would have been 'adequate' following a catastrophic natural disaster, and similarly whether or not the government had mismanaged tsunami relief money'. Thus the authority declined rulings under the accuracy standard about the current affairs programme's claims that the government had not taken sufficient action to restore the water supply for affected locals, the public housing subsidy was inadequate and houses being rebuilt were substandard; and that the aid funds had been 'publicly under-valued' (BSA, 2011, p. 18). The BSA said the complaint should have addressed the balance standard. As the Attorney-General did not raise the controversial issues - viewpoints standard (Standard 4), this was not considered.

The BSA also regarded the Samoa government's recovery report as unclear on loans and donations and the television programme was entitled to rely on this document, provided by the Deputy Prime Minister himself, regardless of whether the figures were accurate. The Samoan government subsequently filed a High Court appeal against the ruling, with Attorney-General Ming Leung Wai declaring the BSA decision 'did not cover all the complaints we had filed' (Tone, 2011). The author of this article was approached for 'assistance' with this appeal by a journalist helping the Samoan government on the basis of an opinion blog posting on Café Pacific that criticised the original programme as 'stunning for its crassness, cultural arrogance and ignorance' and lack of 
evidence 'underpinning the sweeping allegations' (Robie, 2010b). The author rejected this request, saying that although he had criticised the programme he believed strongly in media freedom. A more balanced report of the aid controversy was provided by Alex Perrottet in a series in Pacific Scoop and an interview on Radio New Zealand's Mediawatch programme (Perrottet, 2010; Wilson, 2010). Perrottet reported that the 'jury was still out' on the budget breakdown but gave a detailed rundown on the legacy of devastation, such as: 'Of the 850 households affected, about 502 homes were completely destroyed while 360 suffered severe but reparable damage' (Post-tsunami recovery plan, 2010).

\section{Case study 4: Fiji AG and the Sunday Star-Times over rugby and the regime}

NZ Press Council; publication 30 January 2011

The broadsheet Sunday Star-Times is the largest circulation Sunday newspaper in New Zealand and is the nearest publication that the country has to a national paper. It also has the strongest international and Pacific coverage of any weekly newspaper. Ironically, while the complaint against this paper was about the reportage on Fiji, it was not filed by the Fiji government but by NZ Foreign Affairs Minister Murray McCully. However, the Fiji government exploited the adjudication when the complaint was upheld by the NZ Press Council, targeting one Pacific journalist in particular-Michael Field.

McCully, who also held the one-off portfolio for the Rugby World Cup, complained about a front-page article in the Sunday Star-Times headlined 'FIJI DICTATOR'S WORLD CUP FREEBIE' with a strapline 'MILITARY HARD MAN CAN'T BE KEPT OUT’ (Case 2186, NZ Press Council, 2011, p. 1; Field \& Hinton, 30 January 2011; Press Council rules against newspaper, SST, 10 May 2011). Bylined Michael Field (Fairfax Media's Pacific affairs specialist) and Marc Hinton, the article displayed photographs of Fiji coup leader Commodore Voreqe Bainimarama and his brother-in-law, Francis Kean, with a caption saying the pair 'would be exempt from the visa blacklist imposed after the 2006 coup'. The news story speculated that New Zealand faced the 'embarrassment' of being 'forced' to host the two men. Naval commander Kean was at the time attempting to become chairman of the Fiji Rugby Union (FRU) and if he had succeeded, Bainimarama was expected to become president. Under International Rugby Board (IRB) rules, two officials from 
Fiji could attend the Rugby World Cup in New Zealand between September 9-October 23 while the host country would pick up the costs.

Both men would be hosted at the taxpayer's expense, and their VIP treatment is expected to cost around $\$ 45,000$... Kean and Bainimarama would be hobnobbing with guests including British royals, prime ministers including John Key, Australia's Julia Gillard, Russia's Vladimir Putin and possibly Britain's David Cameron. (Field \& Hinton, 2011)

The news story also included background stating that Kean was a 'convicted killer' (he was actually convicted for manslaughter), comment from a FRU 'insider' tipping Kean and rounded off with comment from NZRFU chief executive Steven Tew explaining that the VIP programme was expensive but standard for such sports events.

McCully argued in his complaint that the claims were incorrect and 'grossly inflated'. He stated he had been forced to issue a media release the same day, explaining the correct situation — that Fiji military regime members could 'apply for an exemption from the sanctions denying them a visa and that the decision made by the Minister of Immigration, under the advice of the Minister of Foreign Affairs, but that 'under current circumstances' any such request would be denied (Case 2186, NZ Press Council, 2011, p. 1).

When the Press Council released its ruling, New Zealand media played the adjudication low key with the Sunday Star-Times publishing it in full on the Stuff.co.nz website on May 10. But the Fiji regime and state-run media such as Fiji Broadcasting Corporation News made considerable mileage out of the adjudication. Although neither of the reporters were named in the ruling, the regime and FBC News singled out Michael Field for attack (NZ Press Council rules against Bainimarama article, FBCN, 11 May 2011):

NZ Foreign Affairs Minister Murray McCully complained against the article written by reporter Michael Field who has been banned from Fiji ... Ruling in McCully's favour, the Press Council says, a fair voice was not sought to balance the claims made in the newspaper report and the complaint is upheld on the grounds of lack of accuracy, fairness and balance.

The Fijian goverment has regularly attacked the credibility of reports written by Michael Field-accusing him of bias and writing false and misleading articles. 
No mention was made of Field's co-author Marc Hinton. Just 14 weeks later, the regime launched another extraordinary personal attack on Field over a news report on the death of a New Zealand tourist (Field, 2011b). Permanent Secretary of Information Sharon Smith-Johns described the report as 'grossly inaccurate, mischievous, insensitive' and deliberately misinforming the public (Koroitanoa, 2011).

\section{Discussion}

There tends to be two main schools of thought about this trend of Pacific governments using the New Zealand media regulatory bodies to target investigative journalists. While New Zealand journalists and Pacific writers based away from their home island nations are generally highly critical and see the trend as 'interfering' with a free press, freedom of expression and investigative journalism, many Pacific journalists and investigative researchers see nothing particularly sinister. Some feel relaxed that governments are using the regulatory bodies and prefer that to the banning of journalists or censorship. There is a general confidence in the fairness and impartiality of New Zealand media watchdogs and their ability to adjudicate on the merits of Pacific cases before them. One Pacific advocacy group is currently lobbying for a universal code of ethics across the region, a difficult objective given the diversity of nations, cultures and media traditions. Some commentators consider that Pacific governments are usually critical of media self-regulation. So a development where governments make use of the regulatory mechanisms is seen as something positive. Former head of the University of the South Pacific regional journalism programme, Shailendra Singh, believes governments do have a right to seek redress through the courts and media councils. But then they should abide by rulings and not protract proceedings in a vindictive manner.

Governments may have sinister motives, but if the system is sound and functional, then nobody should be worried if it is put to the test, even by the autocratic governments of the region. In a way it is a good thing that governments who criticise the system are now using it. It is a good thing also because some wayward journalists who think they can get way with reporting anything about the Pacific will now think twice. It may even improve their reporting. So everyone benefits. (S. Singh, personal communication with author, 15 September 2011) 
Former Papua New Guinean investigative journalist Patrick Matbob, now a journalism school educator at the Divine Word University in Madang, regards it as a natural order for governments to apply pressure. 'Journalists make friends and enemies in their reporting. Enemies will do all they can to discourage the journalist from reporting about them. This would include intimidation by governments, which could be done perfectly legally as is being experienced,' remarked Matbob (personal communication, 13 September 2011). Naturally, this is a concern because Pacific Island governments may succeed in silencing some journalists working in the region.

While journalists such as Michael Field may not have an issue with individuals or governments taking a complaint to media councils - 'I've always viewed journalism as a "global citizen" - they are frequently concerned about 'the bodies themselves not recognising the nature of the complaints' being faced. Field notes:

In the case of the BSA complaint regarding my programme on Nine to Noon, [it] appeared to regard the Fiji military as a sane, balanced and reasonable body. [It] took no account of the fact that it was a military regime and no account of the fact that journalists in Fiji were not blessed with the same freedoms we have [in New Zealand]. In this particular case, I also felt that the BSA was making a ruling on something [it] knew little of.

So far, I have been threatened on numerous occasions by the Fiji regime with being taken to the Press Council. We have followed the process and dealt with their complaints. They have decided not to take the next step and go to the Council. (M. Field, personal communication, 15 September 2011).

Ironically, adds Field, the one case involving him with the NZ Press Council (following the McCully complaint), he 'felt the process was balanced and fair' (ibid.). He also reflects that in the case of the broadcast complaint 'history and time has certainly come down on my side and not the side of Pryde and the BSA' (ibid.).

According to Singh, if governments use media councils, they should not also ban journalists from their countries. However, the media industry upholds these systems of public accountability and cannot complain just because governments are now starting to use them and put these mechanisms to the 
test (S. Singh, personal communication, 15 September 2011). The systems are widely regarded to be able to stand the test as long the reporter has done his or her job faithfully. Singh also considers some governments have their 'not-so-favourite' journalists whom they target in various ways.

It's a concern only if journalists don't do their jobs properly. Over many years, some of the reporting in the region by overseas journalists has been pretty shoddy. Some journalists have a cavalier attitude towards the region and have no qualms taking short cuts, or sensationalising, for rather obvious reasons. They seem to think that the standards that apply at home can be left at home when they parachute into the Pacific. (Ibid)

Field believes that the notion of parachute journalism is 'kind of naive' and 'shows no recognition of the realities of reporting these days' (M. Field, personal communication, 12 January 2012). But many Pacific journalists consider such journalists 'spoil the image and good work' of their colleagues who have done a great job reporting the region: 'If journalists are true to their codes and ethics, they have nothing to fear' (S. Singh, personal communication, 15 September 2011). In the case of John Campbell and his producers, Pip Keane and Claudine Maclean, a year later they won the Aotearoa Film and Television Award for 'investigation of the year' for holding the Samoan government to account for aid donations (Campbell Live wins award, PMW, 17 November 2011).

\section{Conclusion}

The issue is that media freedom organisations and advocacy groups should be monitoring and seeking to address media accountability issues in the Pacific in the wake of failure of local self-regulatory systems (Robie, 2004; 2009). Regulatory moves by governments can only be a positive development if they provide fair redress in case of any breaches by journalists. Governments should be encouraged by advocacy groups to use this system instead of the lawcourts and immediately lift bans and censorship on journalists, such as in Fiji. But advocacy groups should also be alert to any potential abuse of the system by governments.

Ironically, at the time of completing this article, the New Zealand Law Commission had announced a wide-ranging national consultation with the objective of reviewing the country's media accountability regime and wrapping both the statutory BSA and Advertising Standards Authority (ASA), and the 
self-regulatory Press Council under a single independent, but statutory, media tribunal (NZ Law Commission, 2012). While this development was greeted with concern by sections of the media industry, managements, journalists and academics were able to make submissions by 12 March 2012. Former Television New Zealand political editor Linda Clark, who has advised the legal firm assisting the Samoan government over its confrontation with TV3's Campbell Live, argues that the Commission's discussion paper is a thoughtful response to the 'technological and content blur' caused by the failure of regulatory bodies to keep up with media convergence (Clark, 2012).

The commission's solution is a new single regulator created by statute to which all complaints about 'news media' would be directed. Unlike the Press Council or the BSA, the new regulator could intervene without any complaint being laid and - possibly — even before a story is published where there are concerns about the methods the journalist used to gather information.

The reality is that widespread public disillusionment (Bacon, 2012; Tiffen, 2012) over the credibility and accountability of news media has reached a new peak with national soul-searching also in Britain (Leveson Inquiry, 2011) in the wake of the News of the World phone-hacking scandal, and in Australia where a recent Finkelstein Report (2012) recommending a new all-media regulatory tribunal unleashed a stormy debate (see Tiffen et al., 2012). Ironically, while leading mainstream media have defected from the besieged Australian Press Council, some independent online media such as Crikey have recently joined the Council to 'beef up' resources to 'remedy media mistakes' (Black, 2012). Media regulatory and self-regulatory bodies such as the BSA and Press Council in New Zealand need to commit to a greater knowledge of the Pacific to ensure they are not being manipulated by cynical governments.

\section{Note}

1. The Media Council of PNG was first established in 1985 but is currently moribund pending a fraud inquiry. The council's website states that its role is a 'watchdog, agenda-setter and a gatekeeper'. In recent years it has had two major programmes, Media for Development Initiative (MDI) and the Development Communication Initiative (DCI). AusAID was funding the MDI programme but in June 2011 suspended its grants after an audit 'found anecdotal evidence of fraud' (Fox, L. (2011, June 3). PNG media council embroiled in fraud audit, ABC News.) 


\section{References}

Attorney-General of Samoa and Television New Zealand Ltd.-2009-066. (2010, March 2). Broadcasting Standards Authority (BSA).[Determination]. Retrieved on 30 August 2011, from www.bsa.govt.nz/decisions/show/2628

Attorney-General of Samoa and TVWorks Ltd. - 2010-188. (2011, May 5). Broadcasting Standards Authority. (BSA). [Determination]. Retrieved on 30 August 2011, from www.bsa.govt.nz/decisions/show/416

Bacon, W. (2012, March 6). Why the market can't ensure a free press, New Matilda. Retrieved on 6 March 2012, from http://newmatilda.com/2012/03/06/why-marketcant-ensure-free-press

Black, S. (2012, March 19). Why Crikey is joining the press council, Crikey. Retrieved on 20 April 2012, from www.crikey.com.au/2012/03/19/why-crikey-has-joinedthe-press-council/

Brown, R. (2010, April 13). Media freedom in the Pacific, Hard News [Weblog]. Retrieved on 30 August 2011, from http://publicaddress.net/hardnews/mediafreedom-in-the-pacific/

BSA upholds radio complaint against Radio NZ. (2008, September 15). Stuff.co.nz Retrieved on 30 August 2011, from www.stuff.co.nz/national/politics/628873/ BSA-upholds-complaint-against-Radio-NZ

Campbell Live wins award for Samoa tsunami investigation (2011, November 17). Pacific Media Watch. Retrieved on 20 November 2011, from www.pmc.aut. ac.nz/pacific-media-watch/nz-campbell-live-wins-award-samoa-tsunami-moneyinvestigation-7729

Campbell calls PM 'coward'. (2010, October 29). Samoa Observer. Retrieved on 30 August 2011, from www.samoaobserver.ws/index.php?option=com_content\& task $=$ view \&id $=28880 \&$ Itemid $=62$

Clark, L. (2012, January 20). Watchdogs must keep up with media's changing face, Pacific Media Centre Online. Retrieved on 8 February 2012, from www.pmc.aut. ac.nz/articles/watchdogs-must-keep-medias-changing-face

Dreaver, B. (2009, April 6). NZ drug trade fuels Samoa gun smuggling. Television New Zealand. Retrieved on 31 August 2011, from http://tvnz.co.nz/national-news/ nz-drug-trade-fuels-samoa-gun-smuggling-2622603/video?vid=2622663

Field, M., and Hinton, M. (2011, January 30). Fiji dictator's World Cup freebie. Sunday Star-Times. Retrieved on 30 August 2011, from www.stuff.co.nz/sunday-star-times/ news/4597596/Fiji-dictators-World-Cup-freebie

Field, M. (2011, August 21). 'Strange' death in the Blue Lagoon. Sunday Star-Times. Retrieved on 30 August 2011, from www.stuff.co.nz/world/south-pacific/5480462/ Strange-death-in-the-Blue-Lagoon

Field, M. (1984). Mau: Samoa's struggle against New Zealand oppression. Auckland. Reed.

Finkelstein Independent Media Inquiry. (2012). Independent Media Inquiry Report, 28 February 2012. Available at: www.dbcde.gov.au/digital_economy/independent_media_inquiry 
Francis, C. (2010, March 9). TVNZ slammed over Samoa report, stuff.co.nz. Retrieved on 30 August 2011, from www.stuff.co.nz/world/south-pacific/3421960/TVNZslammed-over-Samoa-report

Fiji regime accuses Radio NZ, Fairfax journalist of 'bias' (2008, March 27). Stuff. co.nz Retrieved on 30 August 2011, from www.stuff.co.nz/world/332991/Fijiregime-accuses-Radio-NZ-Fairfax-journalist-of-bias

Grynberg, R., Munro, D., and White, M. (2002). Crisis: The collapse of the National Bank of Fiji. Canberra: Crawford House Publishing

Koroitanoa, S. (2011, August 23). Regime attacks NZ journalist over death report. Pacific Media Watch, citing Fijivillage.com. Retrieved on 23 August 2011, from www.pmc.aut.ac.nz/pacific-media-watch/fiji-regime-attacks-nz-journalist-overdeath-report-7583

Leveson Inquiry. (2011). Culture, practice and ethics of the press. Available at: www. levesoninquiry.org.uk/

Matbob, P. (2011). The state of investigative journalism and the growing impact of new media in PNG. In Papoutsaki, E., McManus, M., and Matbob, P. (Eds.), Communication, culture and society in Papua New Guinea: Yu tok wanem?, (pp. 33-42). Madang, PNG: Divine Word University Press; Auckland: Pacific Media Centre.

Michael Field fields it as it is (2008, September 16). Discombulated Bubu [Blog reposting]. Retrieved on 30 August 2011, from http://discombobulatedbubu.blogspot. com/2008/09/michael-field-fields-it-as-it-is.html

Murray McCully against Sunday Star-Times (2011, May). Case number: 2186, New Zealand Press Council. [Ruling]. Retrieved on 20 August 2011, from www.presscouncil.org.nz/display_ruling.php?case_number $=2186$

NZ Law Commission (2011). The news media meets 'new media': Rights, responsibilities and regulation in the digital age. [Policy discussion paper]. Retrieved on 12 January 2012, from

www.lawcom.govt.nz/sites/default/files/publications/2011/12/ip27-all-web-v2.pdf

Perrottet, A. (2010, October 13). Samoa tsunami report outlines damage, aid effortsbut silent on funding. Pacific Scoop. Retrieved on 30 August 2011, from http:// pacific.scoop.co.nz/2010/10/samoa-tsunami-report-outlines-damage-aid-effortsbut-silent-on-funding/

Perrottet, A. and Robie, D. (2011). Pacific media freedom 2011: A status report. Pacific Journalism Review, 17(2), pp. 148-186. Retrieved on 12 January 2012, from www.pjreview.info/sites/default/files/articles/pdfs/PJR17_2_pacific\%20 media\%20freedom 2011.pdf

Post-tsunami recovery plan for 2010-2013 (2010). Samoan government, [Samoa Observer]. Retrieved on 12 January 2012, from www.samoaobserver. ws/index.php?option $=$ com_content $\&$ view $=$ article $\&$ id $=27784$ :your-tsunamireport\&catid $=1$ :latest-news\&Itemid $=50$

Press Council rules against newspaper. (2011, May 10). Sunday Star-Times. Retrieved on 30 August 2011, from www.stuff.co.nz/sunday-star-times/news/4984890/PressCouncil-rules-against-newspaper 
Pryde and Radio New Zealand Ltd.-2008-040. (2008, August 27). Broadcasting Standards Authority [Determination]. Retrieved on 30 August 2011, from www. bsa.govt.nz/decisions/show/2758

Richards, V. (2010, March 8). BSA decision available: TVNZ Pacific correspondent Barbara Dreaver. Pacific Eyewitness [blog]. Retrieved on 7 July 2011, from http:// pacificeye.wordpress.com/2010/03/08/broadcasting-standards-ruling-in-full-tvnzdreaver-versus-samoa/+BSA+decision+available+Pacific + Eye \&cd=1\&hl=en\&ct $=\mathrm{clnk} \& \mathrm{gl}=\mathrm{nz} \& \mathrm{client}=$ firefox-a

Robie, D. (2010a, March 5). Samoan, 'gangs, drugs and guns' too gung-ho for the BSA. Café Pacific [blog]. Retrieved on 31 August 2011, from http://cafepacific. blogspot.com/2010/03/samoan-gangs-drugs-and-guns-too-gung-ho.html

Robie, D. (2010b, November 1). A Samoan side to Campbell Live-Tuilaepa's 'Kiwi nemesis'. Café Pacific [blog]. Retrieved on 31 August 2011, from http://cafepacific. blogspot.com/2010/11/samoan-side-to-john-campbell-tuilaepas.html

Robie, D. (2010c, October-November). The darker side of paradise. The Walkley Magazine [Review], p. 49.

Robie, D. (2009). Behind the Fiji censorship: A comparative Fiji regulatory case study as a prelude to the Easter putsch. Pacific Journalism Review, 15(2): 85-116.

Robie, D. (2008, March 12). Niu FM in the hot seat over its news credibility. Café Pacific [blog]. Retrieved on 31 August 2011, from http://cafepacific.blogspot. com/2008/03/niu-fm-in-hot-seat-over-its-news.html

Robie, D. (2004). The sword of Damocles in the South Pacific: Two media regulatory case studies. Pacific Journalism Review, 10(1), pp. 103-122.

Samoa police commissioner provides testimony in gun smuggling inquiry (2008, November 15). Samoa News. Retrieved on 30 November 2011, from www.samoanewsonline.com/viewstory.php?storyid $=2158$

Samoa police commissioner provides testimony in gun smuggling inquiry (2008, November 22). GunPolicy.org Retrieved on 30 August 2011, from www.gunpolicy. org/firearms/citation/news/57

Samoa tsunami: Has aid been used effectively? (2010, September 27). Campbell Live, TV3 [Video]. Retrieved on 30 August 2010, fro www.3news.co.nz/Samoatsunami-Has-aid-been-used-effectively/tabid/367/articleID/178364/Default.aspx

Simpson, S. (2011, June 14). Analysis: An overview of the media environment. PMW (Pacific Media Watch). Retrieved on 30 August 2011, from www.pmc.aut.ac.nz/ pacific-media-watch/2011-06-14/fiji-analysis-overview-media-environment

Sioa, P. (n.d., approx. 22 November 2008). Samoa's police commissioner reprimanded, Nafanua skipper demoted. Samoalive Newsline. Retrieved on 30 August 2011, from www.samoanewsonline.com/viewstory.php?storyid $=3663$

Standards body slams Field (2008, September 15). Fiji Broadcasting Corporation News. Retrieved on 30 August 2011, from www.radiofiji.com.fj/fullstory. php?id $=14363$

Tiffen, R. (2012, March 16). Finkelstein media: Volume of vitriol in inverse proportion to amount of evidence, Pacific Media Centre Online. Retrieved on 20 April 
2012, from www.pmc.aut.ac.nz/articles/finkelstein-media-volume-vitriol-inverseproportion-amount-evidence

Tone, C. (2011, June 15). Samoa files High Court appeal over Campbell Live's 'sullied' reputation. Pacific Scoop republished from Samoa Observer. Retrieved on 30 August 2011, from http://pacific.scoop.co.nz/2011/06/samoa-takes-lawsuitagainst-campbell-live-over-sullied-reputation/

Two senior Samoa police officers escape criminal charges over gun smuggling (2009, January 30). Radio New Zealand International. Retrieved on 30 August 2011, from www.rnzi.com/pages/news.php?op=read\&id $=44507$

TVNZ staff profile: Barbara Dreaver (2004). TVNZ website. Retrieved on 30 August 2011, from http://tvnz.co.nz/national-news/barbara-dreaver-431021

UNESCO (United Nations Educational, Scientific and Cultural Organisation). (2011). Freedom of information: The right to know: Proceedings of World Press Freedom Day 2010. Paris. Retrieved on 20 August 2011, from www.unesco.org/new/en/ communication-and-information/resources/news-and-in-focus-articles/all-news/ news/proceedings_report_for_unescos_world_press_freedom_day_2010_celebration available online/

Week nights on Campbell Live (2011). TV3 Website. Retrieved on 30 August 2011, from www.3news.co.nz/TVShows/CampbellLive/Home.aspx

Where has the tsunami relief money gone? (2010, November 1). Campbell Live TV3. [Video]. Retrieved on 30 August 2011, from www.3news.co.nz/Where-has-thetsunami-relief-money-gone/tabid/367/articleID/184117/Default.aspx

Wilson, C. (2010, November 8). Samoa tsunami aid disaster report now under fire in Mediawatch episode. Pacific Scoop. Retrieved on 30 August 2011, from http:// pacific.scoop.co.nz/2010/11/samoa-tsunami-aid-disaster-report-now-under-firein-mediawatch-episode/

Yamo, H. (2012, April 19). South Pacific investigative journalists face threats, victimisation, says PNG reporter, Pacific Scoop. Retrieved on 20 April 2012, from: http://pacific.scoop.co.nz/2012/04/pacific-investigative-journalists-face-threatsvictimisation-of-families-says-png-reporter/

Professor David Robie is director of the Pacific Media Centre, AUT University, Aotearoa/New Zealand. He was head of journalism at both the Universities of Papua New Guinea and the South Pacific (Fiji). He is author of Mekim Nius: South Pacific media, politics and education and publishes the independent media freedom blog Café Pacific: www.cafepacific.blogspot.com An earlier version of this article was presented at the 'Back to the Source' Investigative Journalism conference at the University of Technology, Sydney, in September 2011.

david.robie@aut.ac.nz 